\title{
Gestational Trophoblastic Neoplasm Clinical Distant Metastasis TNM Finding v8
}

National Cancer Institute

\section{Source}

National Cancer Institute. Gestational Trophoblastic Neoplasm Clinical Distant

Metastasis TNM Finding v8. NCI Thesaurus. Code C140017.

A clinical finding about one or more characteristics of a gestational trophoblastic neoplasm, following the rules of the TNM AJCC v8 classification system as they pertain to distant metastases. 